\title{
A foreign body mimicking tracheal stenosis
}

\author{
Ahmet Sizlanan ${ }^{1}$, Onur Akcay ${ }^{2}$ \\ ${ }^{1}$ Thoracic Surgery Department, Mardin State Hospital, Mardin, Turkey \\ ${ }^{2}$ Thoracic Surgery Department, Kızıltepe State Hospital, Kızıltepe, Turkey \\ Kardiochirurgia i Torakochirugia Polska 2017; 14 (2): 137-138
}

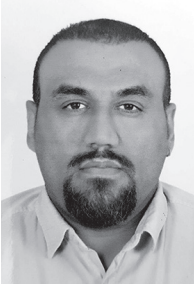

Tracheobronchial foreign body aspiration (FBA) is a lifethreatening emergency that requires prompt removal, but sometimes it may remain undetected because of atypical history or misleading clinical and radiologic findings [1, 2]. Foreign body aspiration can be seen in all ages, but it is most common in children younger than 3 years of age [3]. As a result of symptoms absence, their presentation to the physician may be due to late phase complications [4].

Foreign body aspiration may cause coughing, dyspnea, wheezing in the early period and atelectasis, empyema, bronchiectasis and bronchial asthma-like symptoms in the chronic period [5]. In this study, a case in which bronchial asthma treatment lasted a long time but foreign body aspiration was detected is presented with the literature.

A 10-year-old boy, who had stridor, dsypnea, wheezing and cough, received treatment for diagnosis of bronchial asthma for nearly 2 years. The patient without symptom improvement was presented to our outpatient clinic. Upon physical examination he had stridor and sounds were heard equally in both lungs. There was no pathological findings with chest X-ray. Complete blood count and biochemical parameters showed no pathology. There was shrinkage of the lumen, which was observed approximately $2 \mathrm{~cm}$ under the vocal cords with neck and thorax computed tomography (Figs. 1 A, B). We performed rigid bronchoscopy (RB)
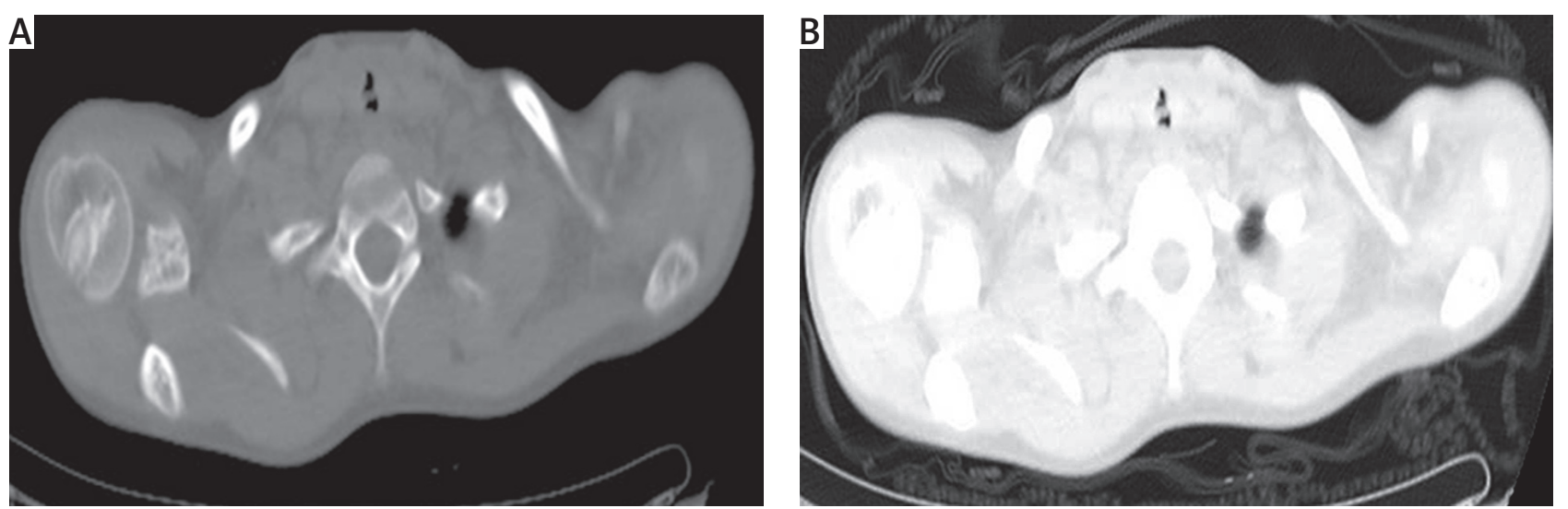

with prediagnosis of tracheal stenosis and FBA. A granuloma encapsulated foreign body $2 \mathrm{~cm}$ inferior to the vocal cords, almost blocking the lumen, was detected and removed with the help of $\mathrm{RB}$. The foreign body which was removed from the trachea was an approximately $15 \mathrm{~mm}$ plastic seal (Figs. 2 A, B). After the RB, his symptoms decreased. He was discharged on the first postoperative day.

Foreign body aspiration is frequent at $1-3$ years of age, but can be observed in all age groups $[3,5]$. History taking is the most important step of the diagnosis [5]. Performing radiological examinations is recommended in all patients suspected of FBA. If the foreign body was radiopaque, it should be visible on the chest $X$-ray. The most common radiographic findings are unilateral hyperaeration, mediastinal shift, atelectasis and pneumonic infiltration. Despite the normal physical examinations and radiographic findings, bronchoscopy is suggested if the clinical suspicion continues $[4,5]$.

Sometimes FBA may remain undetected due to atypical history or misleading clinical and radiological findings. Inflammation and granulation tissue develop around the FBA in delayed cases, and thus it is not uncommon for patients to be treated for other disorders such as persistent fever, asthma or recurrent pneumonia for a long period of time $[6,7]$. Patients with persistent asthma-like symptoms such

Fig. 1 A, B. Thorax computed tomography

Address for correspondence: Onur Akcay, Thoracic Surgery Department, Kızıltepe State Hospital, 47400 Mardin, Turkey, phone: +90 5362160525, e-mail: onur_akcay@yahoo.com Received: 21.12.2015, accepted: 13.01.2017. 

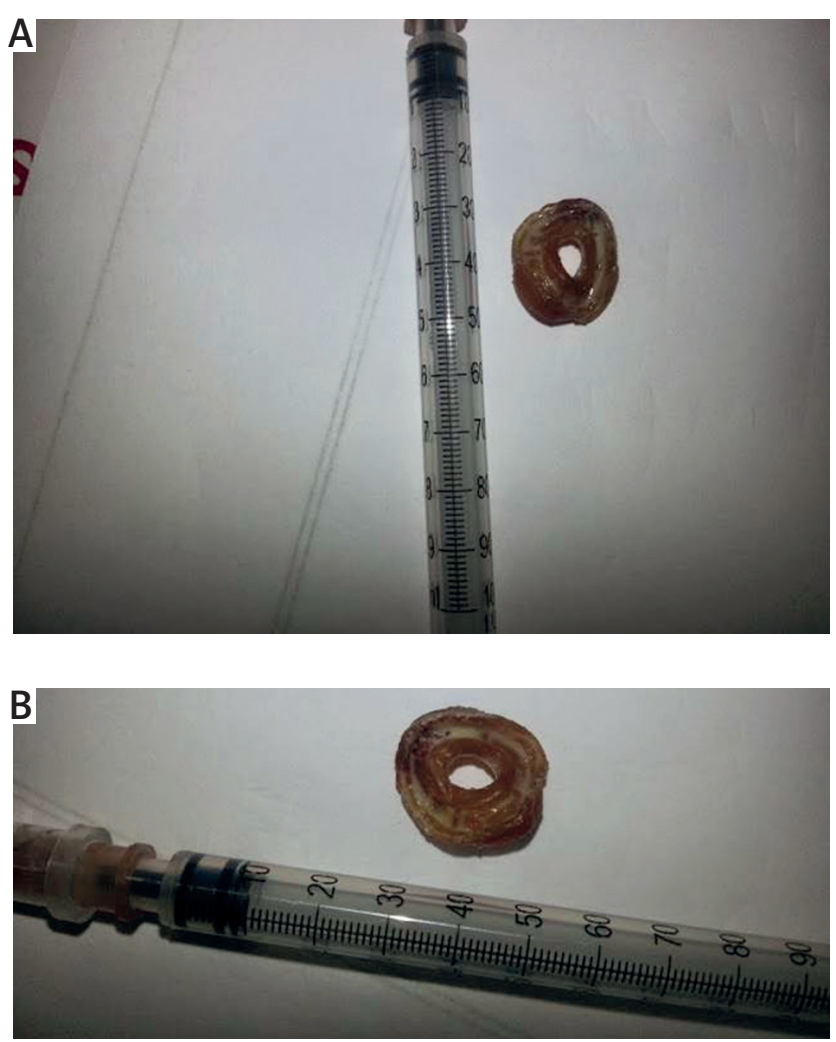

Fig. 2 A, B. Foreign body

as cough and wheezing required treatment with inhaled corticosteroids and bronchodilators [8]. Our patient had wheezing and stridor for nearly 2 years and he was receiving bronchial asthma treatment.

At the present time, observation with rigid bronchoscopy to the tracheobronchial tree remains important [5]. Rigid bronchoscopy is still the most effective method in diagnosis and treatment of FBA [9]. Fiberoptic bronchoscopy (FOB) is not an accepted method for removal of the foreign body [10]. Although FOB has good manipulation and vision, FOB's success rate is $60 \%$, while that of RB is $98 \%$ [11]. Nuts are the most commonly aspirated foreign body in the Western world, while seed aspiration is more commonly reported in the Middle East [12]. We removed the plastic seal with RB in our case.

Atypical or prolonged respiratory symptoms should alert the physician and clinical and radiological findings should be carefully evaluated for possible FBA. Patients with respiratory symptoms, chronic cough and wheezing refractory to medical treatment should be assessed in detail with foreign body aspiration in mind.

\section{Disclosure}

Authors report no conflict of interest.

\section{References}

1. Yıldırım M, Doğusoy I, Okay T, Yaşaroğlu M, Demirbağ H, Aydemir B. Tracheobronchial foreign bodies. Turk Gogus Kalp Dama 2003; 11: 228-231.

2. Sersar SI, Rizk WH, Bilal M, El Diasty MM, Eltantawy TA, Abdelhakam BB, Elgamal AM, Bieh AA. Inhaled foreign bodies: presentation, management and value of history and plain chest radiography in delayed presentation. Otolaryngol Head Neck Surg 2006; 134: 92-99.

3. Midulla F, Guidi R, Barbato A, Capocaccia P, Forenza N, Marseglia G, Pifferi M, Moretti C, Bonci E, De Benedictis FM. Foreign body aspiration in children. Pediatr Int 2005; 47: 663-668.

4. Inal A, Karakoc GB, Kendirli SG, Altıntas DU, Yılmaz M, Hanta I, İnan D, Tuna A, Noyan A. A case with foreign body aspiration who developed cushingoid appearance due to corticosteroids given for misdiagnosis of asthma: case report. J Curr Pediatr 2008; 6: 124-126.

5. Çobanoğlu U, Yalçınkaya I. Tracheobronchial foreign body aspirations. Ulus Travma Acil Cerrahi Derg 2009; 15: 493-499.

6. Tokar B, Ozkan R, Ithan H. Tracheobronchial foreign bodies in children: importance of accurate history and plain chest radiography in delayed presentation. Clin Radiol 2004; 59: 609-615.

7. Chiu CY, Wong KS, Lai SH, Hsia SH, Wu CT. Factors predicting early diagnosis of foreign body aspiration in children. Pediatr Emerg Care 2005; 21: 161-164.

8. Karakoç F, Karadağ B, Akbenlioğlu C, Ersu R, Yildizeli B, Yüksel M, Dağli E. Foreign body aspiration: what is the outcome? Pediatr Pulmonol 2002; 34: 30-36.

9. Senturk E, Sen S. An unusual case of foreign body aspiration and review of the literature. Tuberk Toraks 2011; 59: 173-177.

10. Pasaoglu I, Dogan R, Demircin M, Hatipoglu A, Bozer AY. Bronchoscopic removal of foreign bodies in children: retrospective analysis of 822 cases. Thorac Cardiovasc Surg 1991; 39: 95-98.

11. Limper AH, Prakash UB. Tracheobronchial foreign bodies in adults. Ann Intern Med 1990; 112: 604-609.

12. Karakoc F, Cakir E, Ersu R, Uyan ZS, Colak B, Karadag B, Kiyan G, Dagli T, Dagli E. Late diagnosis of foreign body aspiration in children with chronic respiratory symptoms. Int J Pediatr Otorhinolaryngol 2007; 71: 241-246. 